\title{
Reaction of tomato hybrids carrying the $T y-1$ locus to Brazilian bipartite Begomovirus species
}

\author{
Leonardo Silva Boiteux ${ }^{1,3 *}$; Valter Rodrigues Oliveira ${ }^{1}$; Cézar Honório Silva²; Nozomu Makishima'; Alice \\ K Inoue-Nagata ${ }^{1}$; Maria Esther de Noronha Fonseca ${ }^{1}$; Leonardo de Britto Giordano ${ }^{1,3}$ \\ ${ }^{1}$ Embrapa Hortaliças, C. Postal 218, 70359-970 Brasília-DF, Brasil; ${ }^{2}$ Agência Rural, Av. Carlos de Piva 757, 77150-000 Goianápolis-GO, \\ Brazil; ${ }^{3}$ Fellowship of the National Research Council (CNPq); Ministry of Science \& Technology (MCT). *E-mail: \\ boiteux@cnph.embrapa.br
}

\section{ABSTRACT}

The number of tomato-infecting begomoviruses has increased in Brazil after the introduction of the polyphagous vector Bemisia tabaci biotype B. The Ty-1 locus, introgressed from Lycopersicon chilense, controls tolerance to species of the monopartite Tomato yellow leaf curl virus (TYLCV) complex in Europe and the Middle East. However, little information is available about the $T y-1$ effectiveness against species of the bipartite Begomovirus complex occurring in Brazil. Heterozygous (Ty-1/ty-1) and homozygous (ty1/ty-1) hybrids were evaluated for reaction to Begomovirus isolates under open field conditions in two growing areas in Central Brazil. Test plants were evaluated under natural inoculation with high vector pressure. Evaluation was done using a disease assessment scale (DAS) varying from $1=$ no symptoms to $4=$ severe symptoms. Systemic infection was evaluated via polymerase chain reaction (PCR) using 'universal' Begomovirus primers. In the trial \#1, the hybrids (Ty-1/ty-1) and (ty-1/ty-1) had 35\% and 95\% of plants with symptoms and $75 \%$ and $100 \%$ of plants with positive PCR, respectively. In the trial \#2, only $20 \%$ of the $T y-1 /$ ty -1 hybrid plants were symptom-free with both hybrids displaying $100 \%$ of plants with positive PCR. This reaction of the $T y-1$ hybrid to bipartite Begomovirus species was similar to that reported in Europe and the Middle East to the TYLCV complex with a large number of plants being neither virus-free nor symptom-free. On the other hand, symptom expression of the $T y-1$ hybrid was significantly milder than ty-1/ty- 1 hybrids in both trials (DAS $=1.35$ vs. 2.70 for the trial \#1 and DAS $=2.05$ vs. 3.95 for the trial \#2). Nucleotide sequencing indicated the presence of isolates genetically related to Tomato rugose mosaic virus (ToRMV) in the trial \#1 and a mixed infection of ToRMV and Tomato yellow vein streak virus in the trial \#2. Therefore, the $T y-1$ locus seems to control a "tolerance" response to distinct Begomovirus species. Resistance gene clusters is a common feature in the tomato genome, particularly at the chromosome 6 where Ty- 1 is located. Therefore, additional studies are necessary to confirm if this tolerance to a range of begomoviruses is controlled by $T y-1$ alone or a by the action of distinct, closely linked genes.

Keywords: bipartite geminivirus, Lycopersicon chilense, resistance, tomato.

\section{RESUMO}

Resposta de híbridos de tomateiro contendo o locus $T y$-1 contra espécies brasileiras de Begomovirus de genoma bipartido

O número de espécies de Begomovirus infectando tomateiro no Brasil aumentou significativamente após a introdução do vetor (Bemisia tabaci biótipo B). O locus Ty-1, derivado de Lycopersicon chilense, controla tolerância para isolados de Begomovirus de genoma monopartido pertencentes ao complexo do Tomato yellow leaf curl virus (TYLCV) que ocorre na Europa e Oriente Médio. No entanto, existe escassa informação a respeito da eficiência do locus $T y-1$ contra as diferentes espécies do complexo de Begomovirus de genoma bipartido reportadas no Brasil. Híbridos heterozigotos (Ty-1/ty-1) e homozigotos (ty-1/ty-1) foram avaliados em campo aberto em duas regiões produtoras do Brasil Central. As condições experimentais foram de inóculo natural sob elevada densidade populacional de moscas-brancas virulíferas. A avaliação foi conduzida empregando um índice de severidade de sintomas (ISS) para descrever variando de $1=$ sem sintomas a $4=$ sintomas severos. A frequiência de infecção sistêmica foi avaliada via polymerase chain reaction (PCR) usando "primers universais" para detecção de espécies de Begomovirus. No ensaio 1, os híbridos heterozigotos (Ty-1/ty-1) e homozigotos (ty-1/ty-1) apresentaram $35 \%$ e $95 \%$ de plantas exibindo sintomas e $75 \%$ e $100 \%$ de plantas com PCR positivo para infecção sistêmica, respectivamente. No ensaio 2, observou-se apenas $20 \%$ da plantas do híbrido Ty-1/ty-1 sem sintomas virais, com ambos os híbridos apresentando $100 \%$ da plantas com PCR positivo. A resposta do híbrido contendo o locus $T y-1$ foi similar à reportada para os begomovirus do grupo do TYLCV no Continente Europeu e Oriente Médio, tendo sido observada a presença de plantas sintomáticas e com multiplicação sistêmica do vírus. No entanto, em ambos os ensaios, a expressão de sintomas no híbrido heterozigoto foi mais suave que aquela apresentada pelos híbridos suscetíveis (ISS $=1,35$ vs. 2,70 no ensaio 1 e ISS $=2,05$ vs. 3,95, no ensaio 1). Análise da sequiência do DNA viral indicou a presença de isolados geneticamente relacionados à espécie Tomato rugose mosaic virus (ToRMV) no ensaio 2 e uma infecção mista de ToRMV e Tomato yellow vein streak virus (ToYVSV) no ensaio 2. Estes dados indicam que o locus $T y-1$ confere uma reação do tipo "tolerância" contra distintas espécies de Begomovirus. Estreita ligação de genes de resistência e/ou tolerância a doenças é uma característica do genoma do tomateiro, especialmente no cromossomo 6 onde o locus Ty-1 está posicionado. Desta forma, estudos adicionais são necessários para demonstrar que a tolerância a distintos Begomovirus bipartidos é de fato conferida exclusivamente pelo locus $T y-1$ ou pela presença de outros genes ligados.

Palavras-chave: geminivírus bipartido, Lycopersicon chilense, resistência, tomate.

(Recebido para publicação em 14 de setembro de 2005; aceito em 19 de março de 2007)

$\mathrm{S}$ evere yield losses of tomatoes (Lycopersicon esculentum Mill.) caused by infection of viral species from the genus Begomovirus (Family: Geminiviridae) became a recurrent problem throughout the Mediterranean region, the Middle East, Africa and Southeast Asia (Czosnek \& Laterrot, 1997; Moriones \& Navas-Castillo, 
2000). Begomoviruses are also present in the tomato-producing regions in the New World including North America, Caribbean area, Central and South America (Polston \& Anderson, 1997; Faria et al., 2000).

The viruses predominant in the Old World area are vectored by distinct whitefly (Bemisia tabaci) biotypes and these viruses belong to a group of closely related monopartite species collectively named as the Tomato yellow leaf curl virus (TYLCV) complex (Moriones \& Navas-Castillo, 2000). In Brazil, the variability of the tomato-infecting begomoviruses increased significantly after the introduction of B. tabaci biotype B (= $B$. argentifolii) in the early 1990's (Ribeiro et al., 1994; França et al., 1996). In comparison with the situation in the Old World, the variability of the tomato-infecting begomoviruses in Brazil seems to be higher as revealed by nationwide surveys in which at least eight provisional new Begomovirus species have been reported on tomatoes (Faria et al., 2000; Ribeiro et al., 2003). All the surveys conducted in Brazil indicated the exclusive presence of begomoviruses with bipartite genomes with an apparent absence of monopartite species (Ribeiro et al., 2003; InoueNagata et al., 2004).

Considerable effort has been made to identify resistance genes to begomoviruses through extensive screening of germplasm from cultivated and wild Lycopersicon species. Such screening programs indicated that accessions of the wild species $L$. chilense Dunal are among the best sources of resistance to begomoviruses (Zakay et al., 1991; Michelson et al., 1994; Giordano et al., 1999; Griffiths \& Scott, 2001; Santana et al., 2001). One TYLCV resistance locus from $L$. chilense 'LA 1969' was characterized as being partially dominant and was named as Ty-1 (Michelson et al., 1994). The reaction of the $T y-1$ locus-carrying lines to TYLCV isolates has been described as "tolerance" because the plants became infected (with detectable levels of viral DNA) but displayed attenuated symptom expression. Efforts were made to introgress this locus into $L$. esculentum cultivars (Zamir et al., 1994) and it became one of the most reliable sources of resistance for tomato breeding programs in Europe and Israel. The dominant nature of the $T y-1$ locus allows it to be directly employed for the development of TYLCV tolerant hybrids. A tight linkage of the $T y-1$ locus with susceptibility to root-knot nematodes (Meloidogyne spp.) was observed during the development of TYLCV tolerant inbred lines. Additional studies indicated that the genetic location of $T y-1$ in the tomato map is at the top of the chromosome 6 in close repulsion phase linkage to the $M i$ (rootknot nematode resistance) gene (Zamir et al., 1994; Pan et al., 2000).

Recent reports have indicated good levels of tolerance of $T y-1$ locuscarrying lines to the bipartite Tomato mottle virus (TMoV) in Florida (Scott et al., 1996) and to Brazilian bipartite Begomovirus isolates (Santana et al., 2001; Matos et al., 2003). However, there is a very little of information about the effectiveness of the $T y-1$ locus on individual bipartite Begomovirus species occurring in Brazil. The objective of the present work was to evaluate the levels and spectrum of field tolerance of a hybrid carrying the $T y-1$ locus against species belonging to the Brazilian bipartite Begomovirus complex.

\section{MATERIAL AND METHODS}

One experimental hybrid heterozygous for the $T y-1$ locus and two susceptible (ty-1/ ty-1) hybrids were evaluated for their reaction to Begomovirus in two field trials conducted under natural inoculation with high vector pressure. In the trial \#1, the experimental hybrid (Ty-1/ ty- 1 ) was cultivated together with the susceptible (ty-1/ty-1) hybrid 'Carmen' (Sakata Seed Sudamerica) in Goianápolis, Goiás State, Brazil. In the trial \#2 the same experimental hybrid (Ty-1/ ty-1) was cultivated together with the susceptible hybrid 'Débora Plus' (Sakata Seed Sudamerica) in Leopoldo Bulhões, Goiás State, Brazil. Field evaluations were conducted from February to June (2003) employing standard pest and disease control spray schemes. The experimental design was a complete randomized design with four replications with five plants per plot. Trial \#1 was drip-irrigated while trial \#2 was furrow-irrigated. Individual plants were visually evaluated for their reaction to Begomovirus using a disease assessment scale (DAS) where $1=$ no conspicuous symptoms; $2=$ mild mottling, chlorosis and/or mosaic and restricted to the apical part of the plant; $3=$ intermediate chlorosis and/or mosaic with the plants showing some levels of growth reduction and curling; and 4= overall chlorosis, severe stunting (Giordano et al., 2005). The trait percentage of plants with symptoms was estimated by counting the number of individual plants with DAS varying from 2 to 4 . Plants rated with DAS $=1$ were classified as symptom-free. Evaluations were made 60-70 days after transplanting.

Apical leaf samples of individual plants of each plot in both trials were collected in order to check for systemic Begomovirus infection. Total DNA was extracted using a modified $2 \mathrm{X}$ CTAB buffer and additional purification steps with organic solvents (Boiteux et al., 1999). A segment of the virus DNA-A component was amplified via polymerase chain reaction (PCR) using degenerated primers (PAL1v1978 and PARc496) that have been employed for universal detection of species within the genus Begomovirus (Rojas et al., 1993). PCR amplification products were analyzed by agarose-gel electrophoresis stained with ethidium bromide. Samples with typical Begomovirus PCR amplicon in the gel analyses were scored as positive for systemic infection. Four infected leaf samples showing Begomovirus symptoms were randomly selected in both experimental fields and were used for sequence analysis to determine the corresponding viral species present in the field trials. Sequencing reaction was performed using the BigDye ${ }^{\circledR}$ version 3 (Applied Biosystems) protocol having as template $2 \mu l$ of the PCR mix containing the amplified Begomovirus genomic segment. DNA sequence was analyzed in an Applied Biosystems 3100 
Table 1. Field performance of one experimental tomato hybrid (EH) heterozygous and two tomato hybrids without the Begomovirus tolerance locus $T y-1$ under natural epidemics of two bipartite viral species at two areas in Goiás State (GO), Brazil. Epidemics in Goianápolis (Trial \#1) was caused by the mixture of Tomato rugose mosaic virus (ToRMV) and Tomato yellow vein streak virus (ToYVSV) and epidemics in Leopoldo Bulhões (Trial \#2) was caused by ToRMV. Brasília, Embrapa Hortaliças, 2005.

\begin{tabular}{lcccc}
\hline \multirow{2}{*}{$\begin{array}{l}\text { Parameters employed for } \\
\text { evaluation }\end{array}$} & $\begin{array}{c}\text { Trial \# 1 } \\
\text { Goianápolis (GO) } \\
\text { (ToYVSV and ToRMV) }\end{array}$ & $\begin{array}{c}\text { Trial \# 2 } \\
\text { Leopoldo Bulhões (GO) } \\
\text { (ToRMV) }\end{array}$ \\
\cline { 2 - 5 } & $\begin{array}{c}\text { 'Carmen' } \\
\text { ty-1/ty-1 }\end{array}$ & $\begin{array}{c}\text { 'EH' } \\
\text { Ty-1/ty-1 }\end{array}$ & $\begin{array}{c}\text { 'Débora P' } \\
\text { ty-1/ty-1 }\end{array}$ & $\begin{array}{c}\text { 'EH' } \\
\text { Ty-1/ty-1 }\end{array}$ \\
\hline Disease Score* & $2.70 \mathrm{~A}^{* * *}$ & $1.35 \mathrm{~B}$ & $3.95 \mathrm{~A}$ & $2.05 \mathrm{~B}$ \\
\% plants with symptoms** & $95.00 \mathrm{~A}$ & $35.00 \mathrm{~B}$ & $100.00 \mathrm{~A}$ & $80.00 \mathrm{~B}$ \\
\% plants with positive PCR & $100.00 \mathrm{~A}$ & $75.00 \mathrm{~B}$ & $100.00 \mathrm{~A}$ & $100.00 \mathrm{~A}$ \\
Fruit yield (t/1000 plants) & 4.40 & 3.96 & 2.20 & 4.40 \\
\hline
\end{tabular}

*Disease assessment scale (DAS) where $1=$ no conspicuous symptoms; $2=$ mild mottling, chlorosis and/or mosaic and restricted to the apical part of the plant; $3=$ intermediate chlorosis and/or mosaic with the plants showing some levels of growth reduction and curling; and $4=$ overall chlorosis, severe stunting.

**\% of plants with disease assessment scale (DAS) ranging from 2 to 4 .

***Means with different letter in the same line (in each assay) are not different according to t-test $(5 \%)$.

sequencer at the Genomic Analysis Laboratory (Embrapa Hortaliças). The sequences were compared with GenBank data base using the algorithm BlastN.

A statistical analysis using t-test was employed to compare the means of disease score; percentage of plants with symptoms and percentage of plants with positive PCR. Percentage of plants with symptoms was transformed to $\operatorname{arcsen}(\mathrm{x} /$ $100)^{1 / 2}$. Data with values equal to 100 were transformed to $(100-1 / 4 \mathrm{n})$ before transformation, where $\mathrm{n}$ corresponds to the number of plants used to estimate the percentage of plants without symptoms. The transformation $\mathrm{X}^{1 / 2}$ was done for the data set related to the percentage of plants with positive PCR. For useful comparisons, the commercial fruit yield (transformed to Metric tons per 1,000 plants) was assessed at the growing season end in both trials, but they were not statistically analyzed.

\section{RESULTS AND DISCUSSION}

In the trial \#1, the hybrids (Ty-1/ty1) and (ty-1/ty-1) had $35 \%$ and $95 \%$ of plants with conspicuous Begomoviruslike symptoms and $75 \%$ and $100 \%$ of plants with positive PCR, respectively. In the trial \#2, only $20 \%$ of the hybrid Ty-1/ty- 1 were symptom-free with both hybrids displaying $100 \%$ of plants with positive PCR (Table 1). In both trials, symptom expression of the hybrid with the $T y-1$ locus was significantly more attenuated (milder) than that of the susceptible hybrids (DAS $=1.35$ vs. 2.70 for the trial \#1 and DAS $=2.05$ vs. 3.95 for the trial \#2). Fruit yield of the Ty- 1 hybrid was $100 \%$ higher than the susceptible hybrid under severe epidemic conditions in the trial \#2. However, fruit yield of both hybrids was almost identical in the trial \#1.

New tomato-infecting begomoviruses have been reported in Brazil since the introduction of a new $B$. tabaci biotype. Genetic diversity of tomatoinfecting begomoviruses have been evaluated via sequence comparisons and phylogenetic analyses. At least eight provisional new Begomovirus species were found (Ribeiro et al., 2003). These begomoviruses were initially detected by using 'universal' PCR primers able to amplify conserved fragments of Begomovirus DNA-A and/or DNA-B molecules (Rojas et al., 1993). Here we employed a similar strategy using total DNA extracted from tomato leaves sampled in both trials. In all cases we obtained a single PCR amplicon of approximately $1300 \mathrm{bp}$ corresponding to a segment of the viral DNA-A molecule. Gel analysis of the PCR products obtained from DNA extracted from the leaf samples of the upper (apical) leaves showed the presence of a single virus amplicon (i.e. positive reaction for systemic infection) in $75 \%$ of the plants of the hybrid with the $T y-1$ locus and $100 \%$ in the susceptible (ty-1/ty-1) hybrid in the trial \#1, whereas $100 \%$ of the plants of both resistant and susceptible hybrids were tested positive in the trail \#2. Therefore, the reaction of the $T y-1$ hybrid in our experiment was similar to that reported in Europe and the Middle East to TYLCV where a significant number of plants was neither virus-free nor symptom-free (Rom et al., 1993, Lapidot et al.,1997). A sub-set of these PCR amplicons was selected and sequenced in both 5' and 3' directions. The sequence analyses of the viral isolates occurring in trial \#1 revealed the presence of a mixed infection with the presence of isolates genetically related to Tomato rugose mosaic virus (GenBank accession AF291705) and Tomato yellow vein streak virus (GenBank accession U79998). The sequence analyses of the isolates obtained in trial \#2 indicated the exclusive presence isolates related to Tomato rugose mosaic virus.

It has been common to hear from Brazilian tomato growers that they prefer Begomovirus-susceptible hybrids rather than the currently available tolerant cultivars carrying the $T y-1$ locus. They claim that fruit yield of the susceptible cultivars is sometimes higher even under high incidence of begomoviruses. Our results reinforce the notion that this observation might be correct in specific situations. Differences in fruit yield could result from a great amount of factors related to cultivar performance to management practices, however, it is now well known that infection caused by bipartite begomoviruses can impart significant losses (Giordano et al., 2004).

The already characterized partial dominant nature of the $T y-1$ suggest that tolerance levels to Begomovirus can be increased in tomato hybrids homozygous for this locus. However, homozygous $T y-1$ hybrids have a strong limitation due to the undesirable repulsion phase linkage with root-knot nematode resistance gene $M i$ (Zamir et al., 1994, Pan et al., 2000). Tropical and subtropical soils are often infested with 
root-knot nematodes (Meloidogyne species) and employment of homozygous $T y-1$ hybrids may result in losses due to infection by this group of soil-borne pathogens. Therefore, homozygous hybrids for the Begomovirus tolerance $T y-1$ locus are not expected to became prevalent in Brazil, unless this linkage can be broken.

Ty-1-carrying hybrids displayed high tolerance levels to Tomato yellow vein streak virus isolates in field trials conducted in São Paulo State, Brazil (Matos et al., 2003). In addition, nucleotide sequencing of viral isolates showed the presence of different species in the trials \#1 and \#2. Altogether, these results are indicating that plants carrying the $T y$-1 locus might have a broadspectrum tolerance to tomato-infecting begomoviruses. Clustering of resistance genes is a common feature in the tomato genome, particularly at chromosome 6 were $T y-1$ is located. Additional studies are thus necessary to confirm if the tolerance to more than one bipartite Begomovirus species is controlled by a single gene or a by the action of distinct, closely linked gene(s) at the locus $T y-1$.

\section{ACKNOWLEDGMENTS}

The authors are thankful to William Pereira Dutra (Embrapa Hortaliças) for helping in the PCR analyses and Osmane dos Santos (Embrapa Hortaliças) for his field support.

\section{REFERENCES}

BOITEUX LS; FONSECA MEN; SIMON PW. 1999. Effects of plant tissue and DNA purification method on randomly amplified polymorphic DNA-based genetic fingerprinting analysis in carrot. Journal of the American Society for Horticultural Science 124: 32-38.

CZOSNEK H; LATERROT HA. 1997. Worldwide survey of tomato yellow leaf curl viruses. Archives of Virology 142: 1391-1406.
FARIA JC; BEZZERRA IC; ZERBINI FM; RIBEIRO SG; LIMA MF. 2000. Situação atual das geminiviroses no Brasil. Fitopatologia Brasileira 25: 125-137.

FRANÇA FH; VILLAS-BÔAS GL; CASTELOBRANCO M. 1996. Ocorrência de Bemisia argentifolii Bellows \& Perring (Homoptera:Aleyrodidae) no Distrito Federal. Anais da Sociedade Entomológica do Brasil 25: 369-372.

GIORDANO LB; BEZERRA IC; FERREIRA PTO; BORGES NETO CR. 1999. Breeding tomatoes for resistance to whitefly-transmitted geminivirus with bipartite genome in Brazil. Acta Horticulturae 487: 357-360.

GIORDANO LB; BOITEUX LS; FONSECA MEN; SILVA JBC. 2004. Estimating tomato yield and quality losses due to early Begomovirus infection. Summa Phytopathologica 30: 106 (Abstract).

GIORDANO LB; SILVA-LOBO VL; SANTANA FM; FONSECA MEN; BOITEUX LS. 2005. Inheritance of resistance to Tomato chlorotic mottle begomovirus derived from Lycopersicon esculentum cv. 'Tyking'. Euphytica 143: 27-33.

GRIFFITHS PD; SCOTT JW. 2001. Inheritance and linkage of tomato mottle virus resistance genes derived from Lycopersicon chilense accession LA 1932. Journal of the American Society for Horticultural Science 126: 462467.

INOUE-NAGATA AK; NAVAS-CASTILLO J; MELO PCT; ÁVILA AC. 2004. Busca por Tomato yellow leaf curl virus e Tomato yellow leaf curl Sardinia virus em tomateiros. Horticultura Brasileira 22: 799-800.

LAPIDOT M; FRIEDMAN M; LACHMAN O; YEHEZKEL A; NAHON S; COHEN S; PILOWSKY M. 1997. Comparison of resistance level to tomato yellow leaf curl virus among commercial cultivars and breeding lines. Plant Disease 81: 1425-1428.

MATOS ES; SIQUEIRA WJ; LOURENÇÃO AL; MELO AMT; SAWAZAKI HE; SOUZADIAS JAC; COLARICCIO A. 2003. Resistência de genótipos de tomateiro a um isolado de geminivírus do cinturão verde de Campinas, São Paulo. Fitopatologia Brasileira 28: 159 165.

MICHELSON I; ZAMIR D; CZOSNEK H. 1994. Accumulation and translocation of tomato yellow leaf curl virus in a Lycopersicon esculentum breeding line containing the $L$. chilense tolerance gene Ty-1. Phytopathology 84: 928-933.

MORIONES E; NAVAS-CASTILLO J. 2000. Tomato yellow leaf curl virus, an emerging virus complex causing epidemics worldwide. Virus Research 7: 123-134.
PAN Q; LIU YS; BUDAI-HADRIAN O; SELA M; CARMEL-GOREN L; ZAMIR D; FLUHR R. 2000. Comparative genetics of nucleotide binding site-leucine rich repeat resistance gene homologues in the genomes of two dicotyledons: tomato and arabidopsis. Genetics 155: 309-322.

POLSTON JE; ANDERSON PK. 1997. The emergence of whitefly-transmitted geminiviruses in tomato in the western hemisphere. Plant Disease 81: 1358-1369.

RIBEIRO SG; MELO LV; BOITEUX LS; KITAJIMA EW; FARIA JC. 1994. Tomato infection by a geminivirus in the Federal District, Brazil. Fitopatologia Brasileira 19: 330.

RIBEIRO SG; AMBROZEVÍCIUS LP; DE ÁVILA AC; BEZERRA IC; CALEGARIO RF; FERNANDES JJ; LIMA MF, MELLO RN; ROCHA H; ZERBINI FM. 2003. Distribution and genetic diversity of tomatoinfecting begomoviruses in Brazil. Archives of Virology 148: 281-295.

ROJAS MR; GILBERTSON RL; RUSSELL DR; MAXWELL DP. 1993. Use of degenerate primers in the polymerase chain reaction to detect whitefly-transmitted geminiviruses. Plant Disease 77: 340-347.

ROM M; ANTIGNUS Y; GIDONI D; PILOWSKY M; COHEN S. 1993. Accumulation of tomato yellow leaf curl virus DNA in tolerant and susceptible tomato lines. Plant Disease 77: 253-257.

SANTANA FM, RIBEIRO SG; MOITA AW; MOREIRA JÚNIOR DJ; GIORDANO LB. 2001. Sources of resistance in Lycopersicon spp. to a bipartite whitefly-transmitted geminivirus from Brazil. Euphytica 122: 45-51.

SCOTT JW; STEVENS MR; BARTEN JHM; THOME CR; POLSTON JE; SCHUSTER DJ; SERRA CA. 1996. Introgression of resistance to whitefly-transmitted geminiviruses from Lycopersicon chilense to tomato. In: GERLING D; MAYER RT. (eds.) Bemisia: 1995, Taxonomy, Biology, Damage, Control and Management Andover: Intercept, p. 357-377.

ZAKAY Y; NAVOT N; ZEIDAN M; KEDAR N; RABINOWITCH H; CZOSNEK H; ZAMIR D. 1991. Screening in Lycopersicon accessions for resistance to Tomato yellow leaf curl virus: Presence of viral DNA and symptom development. Plant Disease 75: 279-281.

ZAMIR D; EKSTEIN-MICHELSON I; ZAKAY Y; NAVOT N; ZEIDAN M; SARFATTI M; ESHED Y; HARELE; PLEBAN T; VAN-OSS $\mathrm{H}$; KEDAR N; RABINOWITCH HD; CZOSNEK H. 1994. Mapping and introgression of a tomato yellow leaf curl virus tolerance gene, Ty-1. Theoretical and Applied Genetics 88: 141-146. 